\title{
MODEL PERANCANGAN ORGANISASI BERDASARKAN DORONGAN PASAR
}

\author{
Cecep Hidayat \\ Jurusan Manajemen, Fakultas Ekonomi dan Komunikasi, BINUS University \\ Jln. K.H. Syahdan No. 9, Palmerah, Jakarta Barat 11480 \\ ceceph1267@binus.ac.id
}

\begin{abstract}
Designing Market-Driven Organizations reflects the needs of the customer in the design, roles, and organizational activities. This paper has objectives to review the definitions, concepts, and models relating to the organization based on market needs. The research method used is based on the study of literature references are used as discussion material. The main theories used are the marketing concept, customer value, and design organizations. Conclusion the results of the analysis indicate that the philosophy or concept of marketing is used as the basic design of the organization based on market forces are still relevant to today's conditions.
\end{abstract}

Keywords: customer value, marketing concept, designing organization, market driven organization

\begin{abstract}
ABSTRAK
Perancangan organisasi yang didorong oleh kebutuhan/keinginan pasar (Designing Market-Driven Organizations) mencerminkan kebutuhan nilai pelanggan (customer value) dalam rancangan, peranan-peranan, dan aktivitas-aktivitas organisasi. Penulisan makalah ini bertujuan mengkaji konsep dan model yang berkaitan dengan organisasi berdasarkan kebutuhan pasar. Metode penelitian yang dipergunakan adalah kajian literatur berdasarkan referensi-referensi yang dijadikan bahan pembahasan. Teori-teori utama yang digunakan antara lain adalah konsep pemasaran, nilai pelanggan, dan desain organisasi. Kesimpulan hasil analisis menunjukkan bahwa falsafah atau konsep pemasaran yang dijadikan dasar perancangan organisasi berdasarkan dorongan pasar masih relevan untuk kondisi dewasa ini.
\end{abstract}

Kata kunci: nilai pelanggan, konsep pemasaran, perancangan organisasi, organisasi berdasarkan pasar 


\section{PENDAHULUAN}

Perancangan organisasi yang didorong oleh kebutuhan/keinginan pasar (designing marketdriven organizations) mencerminkan kebutuhan nilai pelanggan dalam rancangan, peranan-peranan, dan aktivitas-aktivitas organisasi. Hal tersebut merupakan landasan bagi implementasi pengelolaan strategi organisasi yang dibangun berdasarkan dorongan atau kebutuhan pasar.

Menurut Craven dan Piercy (2009) Organisasi yang dibangun berdasarkan kebutuhan pasar terkait dalam bagian berkaitan dengan kecenderungan atau prioritas utama pada suatu bidang organisasi yang lebih luas. Struktur organisasi tradisional dirasakan sudah tidak memadai lagi untuk memenuhi persyaratan strategi baru dalam lingkungan yang kompleks dan bergejolak. Pengorganisasian baru yang imperatif didorong oleh teknologi komunikasi, globalisasi produksi , penjualan, dan pelimpahan tanggung jawab untuk organisasi luar bagi fungsi bisnis utama. Desain organisasi menekankan inovasi, produktivitas pengetahuan pekerja, manajemen budaya yang sejalan dengan strategi, bekerja kolaboratif dalam dan di luar perusahaan, jaringan informal, dan mekanisme organisasi untuk mengelola hubungan eksternal dengan mitra organisasi. Desain dan pengelolaan proses organisasi telah menjadi isu kunci dalam perancangan. Organisasi sedang dirancang untuk mencapai kegesitan dan fleksibilitas, serta untuk mengakomodasi tantangan-tantangan baru dalam keterlibatan karyawan dan motivasi.

Kecenderungan yang telah disebutkan sebelumnya dalam desain organisasi berhubungan dengan pengorganisasian untuk strategi organisasi berdasarkan kebutuhan pasar dan pencapaian strategi yang efektif. Secara khusus, dampak dari pelanggan pada pilihan desain mengamanatkan mempertimbangkan keselarasan organisasi dengan pasar, dan struktur yang berkembang untuk mencapai tujuan ini. Penekanan ditempatkan pada pengelolaan proses pemasaran yang melintasi batasbatas organisasi tradisional dan menekankan prioritas yang tinggi untuk lintas-fungsional dan integrasi yang efektif sebagai pendorong nilai pelanggan.

Beberapa pertanyaan penting berpusat pada organisasi sumber daya pemasaran. Pilihan desain yang dihadapi dalam sentralisasi atau desentralisasi organisasi pemasaran, dan integrasi difusi tanggung jawab untuk tugas-tugas pemasaran. Tidak ada satu cara perancangan yang cocok dengan semua situasi, dan faktor-faktor situasional penting sekitar pilihan desain. Dalam kelompok sumber daya pemasaran, pilihan struktural utama sebuah struktur organisasi adalah antara struktur fungsional, produk, pasar, atau desain matriks. Pertimbangan juga harus diberikan kepada identifikasi peran pemasaran baru dan spesialisasi sebagai peran pemasaran yang berkembang dalam sebuah perusahaan. Salah satu isu utama adalah kemitraan, baik secara internal, misalnya, dalam organisasi usaha pemasaran, maupun eksternal dalam bekerja dengan mitra pemasaran. Dalam beberapa kasus organisasi jaringan (net worked organization) akan menjadi sebuah perkembangan penting.

Strategi pemasaran global dan pelanggan global mengidentifikasi beberapa tuntutan organisasi tambahan. Pemasaran global sering bergantung pada aliansi strategis. Program global menyiratkan pilihan organisasi mengenai lokasi internasional dari fungsi bisnis perancangan bentuk-bentuk organisasi yang tepat untuk memenuhi tantangan tambahan dari koordinasi dan komunikasi internasional. Suatu pertumbuhan globalisasi pelanggan di banyak sektor mengarah pada respon organisasi dari pengembangkan struktur global dan proses manajemen. Harapan pembeli baru bagi suatu titik tunggal kontak dengan pemasok bersama dengan ketentuan perdagangan yang seragam dan standarisasi dari produk dan jasa di seluruh dunia sering menunjukkan perlunya design organisasi di tingkat global untuk mengelola hubungan pelanggan tersebut. 


\section{METODE}

Metode penelitian yang digunakan dalam penulisan makalah ini adalah kajian literatur yang berupaya menganalisis konsep dan pengembangan model dari referensi- referensi yang dijadikan acuan dan bahan analisis. Adapun referensi utama yang dijadikan bahan analisis adalah berupa jurnaljurnal utama yang terpilih yang berkaitan dengan model perancangan organisasi yang didorong oleh kebutuhan pasar (market-driven organizations). Selain jurnal-jurnal utama, untuk melengkapi kajian literatur juga dikaji beberapa buku teks sebagai bahan kajian.

\section{HASIL DAN PEMBAHASAN}

Craven \& Piercy (2009) mengemukaan bahwa pengorganisasian untuk strategi berdasarkan dorongan pasar (market driven strategy) terdiri atas: (1) pemasaran strategis dan struktur organisasi; (2) penyesuaian organisasi dengan pasar yang meliputi: informasi lateral informal, mekanisme pengintegrasian, dan penyesuaian penuh dengan pelanggan; (3) fungsi-fungsi pemasaran dengan proses-proses pemasaran; dan (3) pemasaran sebagai proses lintas fungsional yang meliputi: pendanaan/akuntansi, operasi, penjualan, riset dan pengembangan, pelayanan pelanggan, dan manajemen sumberdaya manusia.

Perancangan organisasi berdasarkan kebutuhan pasar mengacu pada salah satu falsafah atau konsep pemasaran yaitu falsafah pemasaran. Perkembangan falsafah pemasaran dimulai dari falsafah produksi, produk, penjualan, pemasaran, dan pemasaran sosial. Aspek dasar dari perancangan organisasi berdasarkan dorongan kebutuhan pasar (market driven organizations) adalah pasar/pembeli yang tidak lain adalah konsumen itu sendiri, baik itu calon konsumen (potential buyer), konsumen (buyer), atau pelanggan (customer). Nilai pelanggan (customer value) tidak lain adalah manfaat (benefit) dibandingkan dengan biayanya (cost). Jika dikaitkan dengan empat bauran pemasaran utama (marketing mix) adalah product, place, dan promotion dibagi dengan price . Lebih terperinci lagi nilai pelanggan adalah fungsi produk, jasa, personalia, dan kesan produk dibandingkan dengan biaya yang berupa uang, energi yang dikeluarkan, waktu yang dipergunakan, dan biaya psikologis. Setiap organisasi atau perusahaan harus berupaya bagaimana menciptakan benefit yang paling maksimum dengan biaya (cost) yang paling minimum. Setiap organisasi dalam rangka mencapai kinerja yang superior harus berupaya menciptakan superior customer value yang mengandung makna bahwa nilai yang dirasakan oleh pelanggan yang diciptakan harus melebihi nilai pelanggan yang diciptakan para pesaingnya.

$$
\begin{aligned}
\text { Customer value }=\frac{\text { Benefit }}{\text { Cost }} & =\frac{\text { Product }+ \text { Place }+ \text { Promotion }}{\text { Price }} \\
& =\frac{\text { Product Function }+ \text { Service }+ \text { Personal }+ \text { Product Image }}{\text { Monetary Cost }+ \text { Energy }+ \text { Time }+ \text { Psychology Cost }}
\end{aligned}
$$

Gambar 1 Nilai yang dirasakan oleh Pelanggan (Customer Perceive Value)

Sumber : Sucherly: 2011, diolah kembali 
Sebuah organisasi pada dasarnya bisa merancang organisasi berdasarkan sumber daya yang dimiliki, bisa juga berdasarkan kebutuhan atau dorongan pasar. Selain itu juga bisa merupakan gabungan antara keduanya dengan derajat masing masing aspek yang dapat Berbeda-beda, mungkin bisa sebagian besar berdasarkan sumberdaya dan sebagian kecil berdasarkan kebutuhan pasar, sebagaian besar berdasarkan kebutuhan pasar dan sebagian kecil berdasarkan sumber daya, atau antara keduanya seimbang. Secara lebih rinci titik berat penekanan tersebut dapat dilihat dalam Gambar 1 . Hal tersebut bergantung pada dua kekuatan yang mendominasi dan mempengaruhi organisasi tersebut. Organisasi yang merasa memiliki sumberdaya atau kapabilitas yang unggul dan keunggulan tersebut tidak mudah ditiru oleh para pesaingnya bisa merancang organisasinya berdasarkan kapabilitas internal tersebut (resource driven) atau dalam istilah lain pasar terggantung pada perusahaan (marketdriving). Sebaliknya apabila organisasi merasa tidak memiliki kapabilitas yang bisa diunggulkan ia bisa menerapakan perancangan organisasi berdasarkan pasar, jadi dalam hal pasar tidak memiliki ketergantungan terhadap organisasi akan tetapi sebaliknya organisasi bergantung pada dorongan kebutuhan pasar. Selanjutnya bila sebuah organisasi menekankan pada kedua aspek (sumberdaya dan pasar) bisa memilih rancangan organisasi campuran (antara resources dan market kira-kira seimbang). Secara lebih terperinci hubungan antara aspek internal (resources) dan aspek eksternal (market) serta keterkaitannya dengan spanning processes dapat dilihat pada gambar 2.

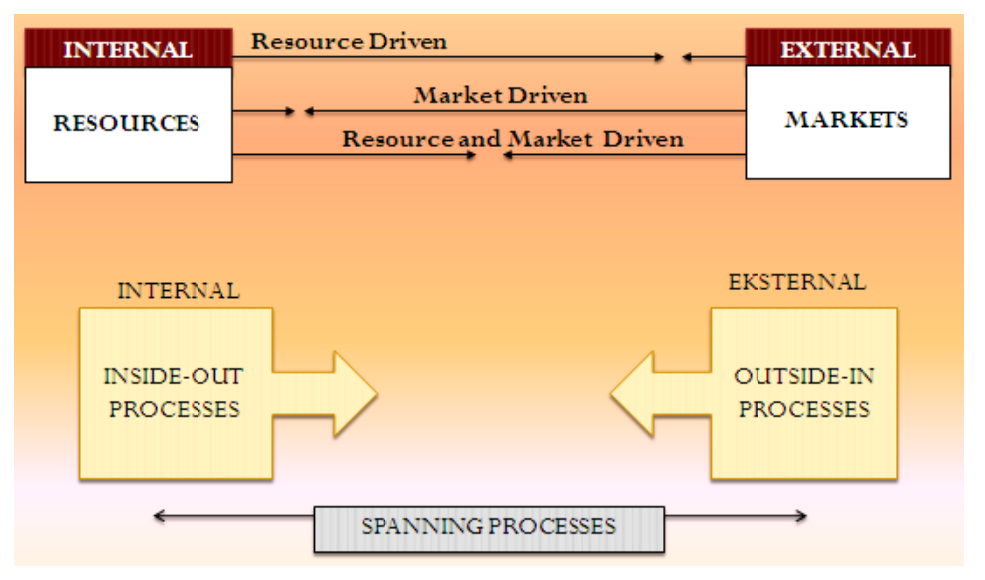

Gambar 2 Orientasi Perusahaan

Sumber : Sucherly : 2011

Sebagian besar literatur pemasaran menganut palsafah/konsep pemasaran yang mendasarkan diri pada kebutuhan pasar atau keinginan pelanggan. Salah satu pendapat antara lain seperti diungkapkan oleh Tilman (2008) berkaitan dengan analisis lingkungan bisnis di masa mendatang. Tilman (2008) mengatakan bahwa ada sekurang-kurangnya enam sumberdaya perubahan bisnis di masa mendatang yang pertama dan paling utama adalah pelanggan (customer). Selanjutnya ia mengatakan bahwa akan bagaimana keinginan konsumen tiga, empat, lima tahun mendatang, akankah kebutuhan mereka sama? Akankah masih berpusat pada kualitas dan biaya? (Tilman, 2008). Pernyataan yang mendukung fokus pelanggan juga dikemukan oleh Reece bahwa membangun strategi adalah dimulai dengan penentuan siapa pelanggan perusahan yang akan kita bangun (Reece, 2010).

Menurut Days (1994), market driven organization memiliki kepekaan perasaan akan pasar (market sensing) yang superior, keterkaitan dengan konsumen (customer linking), dan kemampuan kedekatan dengan para pemasok (chanel bonding capability). Selanjutnya ia mengatakan bahwa proses yang mendasari kemampuan kepekaan pasar yang superior adalah dikelola dengan baik dan dipahami secara efektif, menghantarkan secara superior, menginformasikan dan memandu keduanya, yaitu jangkauan (spanning) dan kemampuan luar-dalam organisasi (Days, 1994). 
Selanjutnya sebagai perbandingan dengan market driven organization (external emphasis) Days mengemukakan juga bahwa penekanan pada aspek internal berkaitan dengan manajemen pendanaan (financial management), pengendalian biaya (cost control), pengembangan teknologi (technological development), logistik yang terpadu (integrated logistic), Proses pabrikasi/ transformasi (manufacturing/transformation processes), manajemen sumberdaya manusia (human resources management) dan kesehatan dan keselamatan lingkungan (environment health and safety). Secara lebih terperinci mengenai kedua penekanaan tersebut beserta aspek-aspek spanning processes-nya dapat dilihat pada Gambar 3.

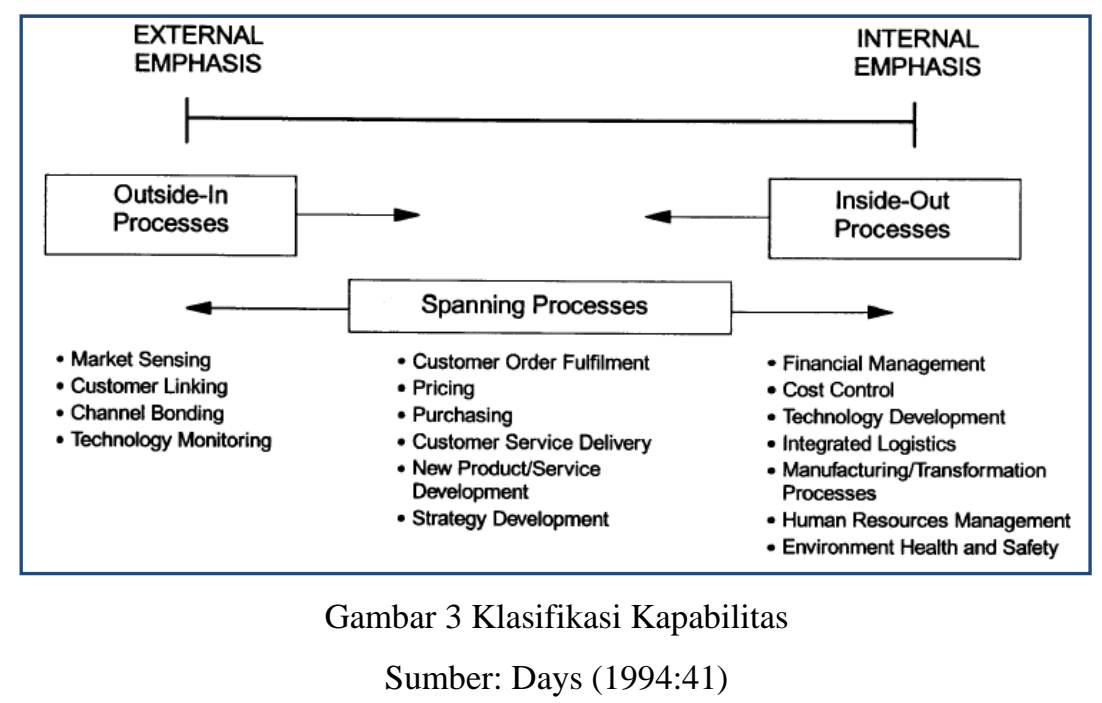

Pendapat senada juga dikemukakan oleh Jaeger (2010) yang mengatakan bahwa inovasi yang didorong oleh kebutuhan konsumen (consumer-driven) telah memfokuskan banyak pada inovasi yang berorientasi pada pengguna. Selanjutnya User driven innovation adalah fenomena pertama yang diamati pada dekade tahun 70an oleh von Hippel. Jaeger mendefinisikan Inovasi yang didorong oleh kebutuhan pengguna (User driven innovation) sebagai proses menuju pengembangan produk atau jasa dimana analisis terintegrasi dan pemahaman keinginan dan kebutuhan konsumen dan pembentukan preferensi memainkan peranan kunci (Jaeger, 2010).

Menurut Carrilat, Jaramillo \& Locander (2004), ada dua pendekatan untuk mendefinisikan organisasi berdasarkan dorongan pasar, yaitu pernyataan yang mengatakan bahwa organisasi berdasarkan pasar (market driven) menunjukkan suatu kemampuan yang superior untuk memahami, menarik dan menjaga valuable para pelanggan. Selain itu juga ia mengatakan kelemahannya dari definisi tersebut, bahwa definisi tersebut mengabaikan unsur pokok pasar yang lain seperti pesaing, pemegang saham, karyawan perusahaan, dan regulator.

Selanjutnya Carrilat et al (2004), dengan mengutip pendapat Jaworski et. al., mengatakan bahwa definisi kedua (tahun 2000-an) dari market driven adalah "pembelajaran, pemahaman, dan ketanggapan terhadap persepsi pemegang kepentingan (stock holder) dan perilaku dalam struktur pasar, (Carrilat et al., 2004, hal. 2). Dalam kerangka konseptual yang dikemukakannya (Gambar 4). Carrilat et al menyatakan istilah resource based dengan istilah market-driving, yang utamanya adalah mengandalkan kapabilitas organisasi yang superior. Dengan kata lain kapabilitas organisasi tersebut melebihi para pesaingnya dan merupakan faktor keunggulan bersaing yang menjadi andalan perusahaan. 
Akan tetapi dalam model tersebut terlihat bahwa meskipun berdasarkan kapabilitas perusahaan yang dimiliki tetapi tetap memperhatikan kesesuaiannya dengan kesempatan-kesempatan yang bisa menciptakan nilai pelanggan. Secara garis besar model tersebut menggambarkan bahwa kepemimpinan transformasional akan membentuk budaya organisasi yang selanjutnya akan menciptakan kapasitas pada inovasi. Kapasitas inovassi akan berpengaruh pada fase transitory dan selanjutnya berpengaruh pada market driving dan pada akhirnya akan berdampak pada kinerja organisasi. Pada kerangka konseptual yang dikemukaan oleh Carrilat terlihat bahwa kesesuaian antara kapabilitas organisasi yang superior dengan kesempatan nilai pelanggan yang bisa diciptakan pada akhirnya akan mempengaruhi kinerja bisnis organisasi yang superior. Kinerja bisnis yang superior dalam arti bahwa kinerja bisnis tersebut lebih unggul dibanding dengan kinerja organisasi-organisasi lain yang menjadi pesaingnya. Akan tetapi kinerja bisnis yang superior tersebut juga dipengaruhi oleh variabel moderat (bisa memperkuat atau memperlemah) yaitu interaksi dengan pelanggan.

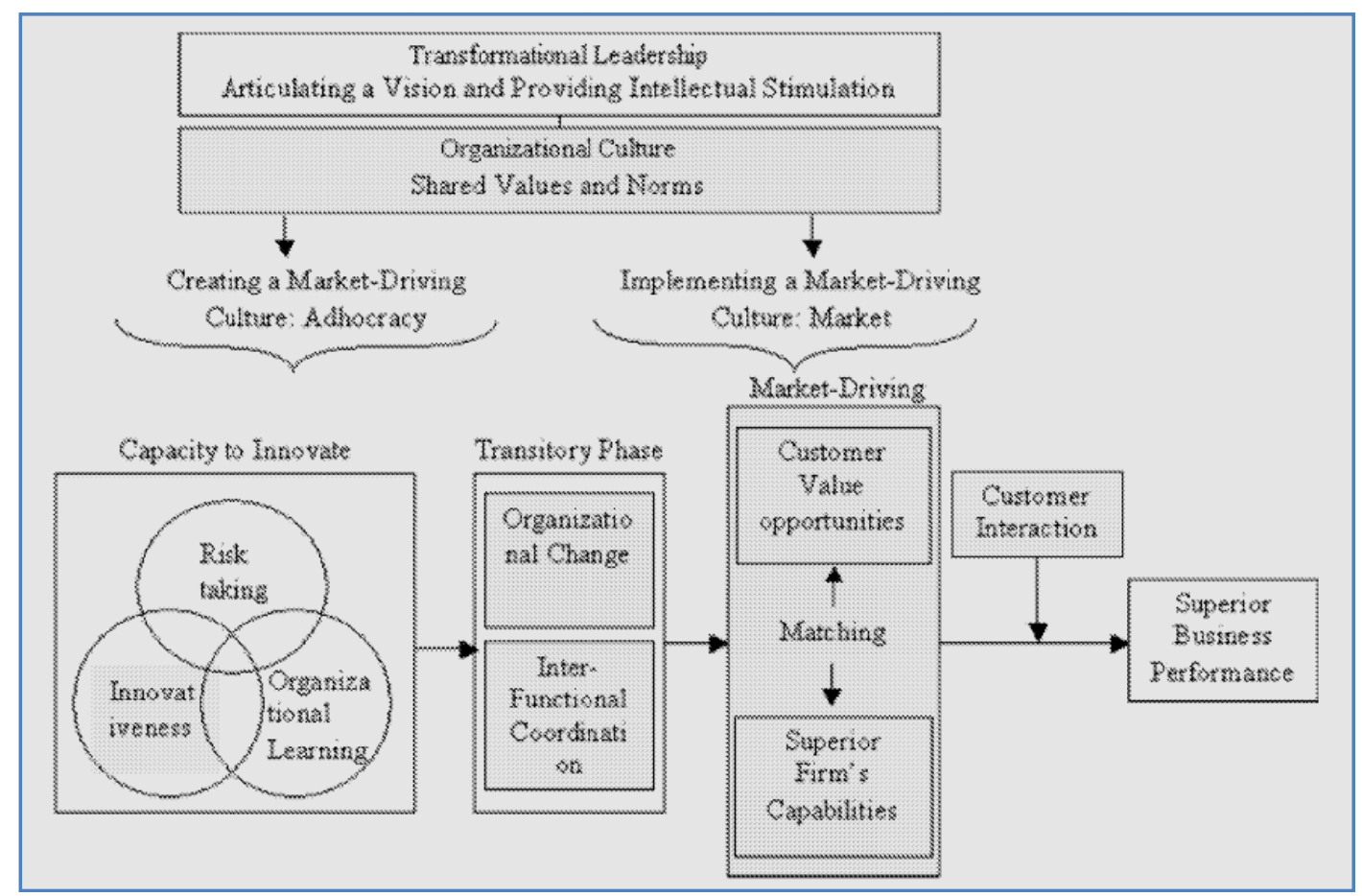

Gambar 4 Kerangka Konseptual Market-driving Strategy

Sumber : Carrilat et al (2004:5)

Berkaitan dengan nilai pelanggan dan kinerja organisasi yang superior juga dikemukakan oleh Sucherly (2011) bahwa terdapat tiga posisional keunggulan organisasi berdasarkan sumberdaya yang menciptakan nilai pelanggan yaitu comparative advantage, competitive advantage, dan cooperative advantage. Selanjutnya ketiga strategi tersebut akan berpengaruh pada keunggulan posisional dan akhirnya berdampak pada kinerja organisasi yang superior. Dalam model tersebut dikemukaan bahwa bila organisasi memiliki sumberdaya yang unik maka ia bisa secara langsung memiliki keunggulan komparatif. Jika perusahaan memiliki nilai yang superior maka ia secara langsung memiliki keunggulan kompetitif. Akan tatepai bila nilai yang superior itu dimiliki oleh pesaing maka organisasi melalui strategi hubungan baik dengan pesaing bisa memilih strategi kooperatif. Secara lebih rinci hubungan antara aspekaspek tersebut dapat dilihat dalam Gambar 5. 


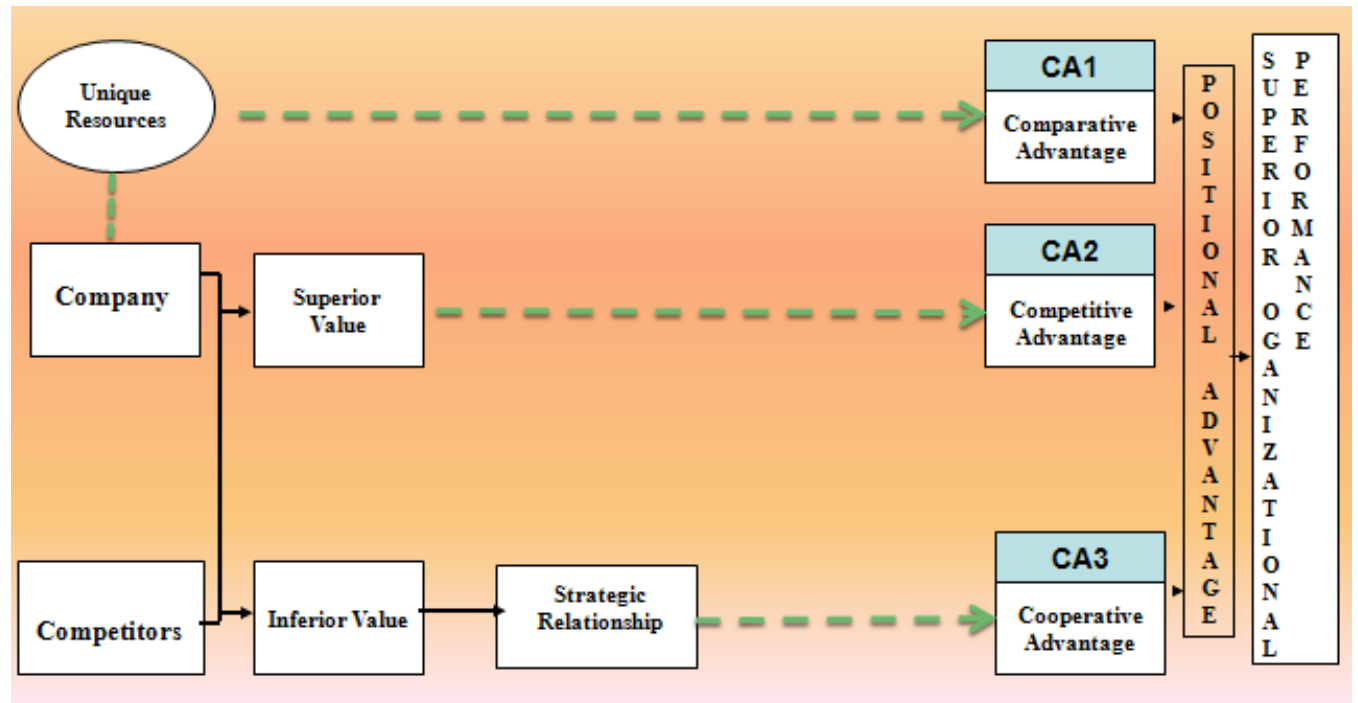

Gambar 5 Positional Advantage Framework

Sumber : Sucherly, 2011

Pernyataaan yang senada mengenai organisasi yang berdasarkan dorongan pasar juga dikemukakan oleh Peters and Fletcher (2004), yang menyebutkan bahwa pendekatan berdasarkan pasar untuk memahami komunikasi dan kerja tim terletak pada tiga prinsip utama, yaitu: (1) memahami komunikasi dan kerja tim adalah suatu hal yang harus diadopsi oleh suatu persfektif jaringan kerja; (2) komunikasi internal antara para pekerja adalah berkaitan erat dan memiliki pengaruh penting pada komunikasi eksternal (dengan mitra bisnis, pemasok dan pelanggan); dan (3) bahwa perluasan pemusatan pandangan dan pemahaman secara kualitas antara jaringan komunikasi adalah fungsi utama komunikasi pemasaran dalam dan antara anggota tim organisasional.

Menurut Koco (1998), organisasi yang didorong berdasarkan kebutuhan pasar meletakkan suatu pada pengembangan produk seputar apa yang konsumen inginkan , butuhkan, dan bersedia membayar. Pernyataan yang menganjurkan perhatian pada pelanggan sebagai dasar dari organisasi berdasarkan dorongan pasar juga dikemukakan oleh Herzlinger (2000) dalam penelitian pelayanan medisnya yang mengatakan bahwa untuk mengurangi biaya dengan meminimalisir kesalahan adalah tidak lain dengan fokus pada penyederhanaan proses melakukan perhatian terhadap pelanggan, memantau kualitas, dan pengukuran biaya.

Dari kutipan pendapat-pendapat yang telah dikemukakan, dapat disimpulkan bahwa hampir semua memiliki kesamaan unsur yaitu pasar atau pelanggan sebagai unsur dasar perancangan organisasi. Dengan demikian perancangan organisasi berdasarkan dorongan kebutuhan pasar (market driven organization) masih relevan dan mutlak dilakukan apabila akan merancang suatu organisasi atau perusahaan. Diantara lima falsafah manajemen pemasaran, falsafah dasar pemasaran (marketing concept) yang berakar pada kebutuhan pelanggan masih relevan dengan kondisi organisasi bisnis dewasa ini. 


\section{SIMPULAN}

Perancangan organisasi yang didorong oleh kebutuhan/keinginan pasar (Designing MarketDriven Organizations) mencerminkan kebutuhan nilai pelanggan dalam rancangan, peranan-peranan, dan aktivitas-aktivitas organisasi. Perancangan organisasi berdasarkan dorongan pasar menekankan pada aspek ekternal dalam spanning processes. Walaupun model market driven menjadi suatu alternatif dalam situasi dan kondisi yang dinamis akan tetapi pada dasarnya tidak ada satupun rancangan organisasi yang sesuai untuk semua situasi dan kondisi. falsafah dasar pemasaran (marketing concept) yang berakar pada kebutuhan pelanggan masih relevan dengan kondisi organisasi bisnis dewasa ini.

\section{DAFTAR PUSTAKA}

Craven, D. W., \& Piercy, N. F. (2009) Strategic marketing. New York: McGraw-Hill International.

Carrilat, F. A., Jaramillo, F., \& Locander, W. B. (2004). Market-driving organizations: A framework. Academy of Marketing Science Review, Volume: 2004, Issue: 05, Pages: 1-14.

Days, G. S. (1994). The capabilities of market driven strategy. Journal of Marketing , Vol. 58, No. 4 (Oct., 1994), pp. 37-52.

Herlinger, R. (2000). Market-driven, focused healthcare: The role of managers. Frontiers of Health Services Management 16, no. 3 (2000): 3-12.

Jaeger, S. R. (2010). Consumer-driven innovation in food and personal care products. Philadelphia: Woodhead.

Koco, L. (1998) Market-driven products make sense for some. National Underwriter Life \& Health, Oct 5, 1998; 102, 40, pg 25.

Peters, L. D., \& Fletcher, K. P. (2004). A market-based approach to understanding communication and team working: A multi-disciplinary literature review. Academy of Marketing Science Review, 8 (5). pp. 1-39.

Reece, M. (2010). Real-time marketing for business growth: How to use social media, measure marketing, and create a culture of execution. New Jersey: Pearson Education.

Sucherly. (2011). Model pemasaran konseptual. .Materi kuliah Program Doktor Ilmu Ekonomi, Universitas Padjadjaran, Bandung.

Tilman, G. (2008). The business oriented CIO: A guide to market driven management. New Jersey: John Willey \& Sons. 